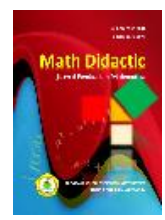

MATH DIDACTIC: JURNAL PENDIDIKAN MATEMATIKA

Volume 5 Nomor 1, Januari - April 2019, halaman 93 - 100

Tersedia Daring pada http://jurnal.stkipbjm.ac.id/index.php/math

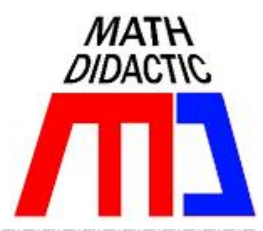

\title{
ANALISIS KESALAHAN DALAM MENYELESAIKAN SOAL PERSAMAAN KUADRAT SISWA SMK KESEHATAN
}

\section{ERRORS ANALYSIS IN SOLVING THE QUADRATIC EQUATION OF HEALTH VOCATIONAL SCHOOL STUDENTS}

\author{
Rahmi Hidayati \\ STIKES Borneo Lestari \\ rahmihidayati.pmatc@gmail.com
}

\begin{abstract}
Abstrak: Tujuan dari penelitian ini untuk mengetahui letak kesalahan dalam menyelesaikan persamaan kuadrat dan ketuntasan belajar pada materi persamaan kuadrat. Sumber data dari penelitian ini adalah siswa SMK kelas X jurusan Farmasi sebanyak 65 orang. Metode yang digunakan dalam penelitian ini adalah metode deskriptif. Teknik pengumpulan data yang digunakan adalah tes dan analisis yang digunakan dengan teknik persentase. Hasil dari penelitian ini adalah letak kesalahan yang dialami siswa dalam menyelesaikan persamaan kuadrat dengan menggunakan rumus abc lebih dominan dengan menggunakan langkah 1 yaitu menentukan nilai-nilai $a, b$, dan $c$ terutama pada persamaan kuadrat yang dinyatakan tidak baku dan ketuntasan belajar siswa belum tercapai.
\end{abstract}

Kata Kunci: analisis kesalahan, persamaan kuadrat, rumus abc

Abstract: The purpose of this study was to find out the location of errors in solving quadratic equations and learning completeness in the material of quadratic equations. The data sources of this study are 65th grade Vocational School students in Pharmacy majoring in. The method used in this research is descriptive method. The data collection technique used is the test and analysis used by percentage techniques. The results of this study are the location of errors experienced by students in resolving quadratic equations using the abc formula more dominant by using step 1 , namely determining the values of $a, b$, and c, especially in quadratic equations which are not standardized and student learning completeness has not been achieved

Keywords: error analysis, quadratic equation, abc formula

Cara Sitasi: Hidayati, R. (2019). Analisis kesalahan dalam menyelesaikan soal persamaan kuadrat siswa SMK Kesehatan. Math Didactic: Jurnal Pendidikan Matematika, 5(1), 93-100. https://doi.org/10.33654/math.v5i1.524 
Dalam kurikulum pendidikan di Indonesia untuk setiap jenjang pendidikan salah satu mata pelajaran yang wajib diajarkan di sekolah adalah matematika. Matematika merupakan salah satu mata pelajaran pokok yang ada sejak pendidikan dasar dan dapat membentuk pola pemikiran yang logis, sistematis, kritis, dan kreatif. Herman Hudojo (2005, hal. 35) mengemukakan bahwa hakikat matematika berkenaan dengan ide-ide, struktur-struktur, dan hubungan-hubungannya yang diatur menurut urutan yang logis. Sementara itu Soedjadi (2000, hal. 42) menyatakan bahwa matematika sekolah adalah unsur-unsur atau bagian-bagian dari matematika yang dipilih berdasarkan atau berorientasi kepada kepentingan dan perkembangan IPTEK. Untuk mendapatkan penguasaan konsep yang baik pada jenjang ini diperlukan pemahaman dan penguasaan materi dari awal yaitu mulai dari pokok bahasan yang diajarkan pada kelas X. Apabila siswa dapat memahami konsep matematika dengan baik yang diajarkan pada kelas sebelumnya, maka siswa akan memahami matematika pada kelas selanjutnya.

Berkaitan dengan pemecahan masalah, berdasarkan kurikulum Nasional, aljabar merupakan salah satu materi matematika yang wajib dipelajari pada satuan pendidikan SMA/MA/SMK/MK. Lebih lanjut, Mahsup (2010, hal. 15) menyatakan bahwa dengan mempelajari konsep aljabar siswa dapat berlatih untuk memecahkan masalah dalam kehidupan sehari-hari yang berkaitan dengan matematika. Salah satu materi aljabar yang erat kaitannya dengan kehidupan sehari-

hari adalah materi persamaan kuadrat pada umumnya yang berkaitan dengan aspek pemecahan masalah. Selain itu, materi ini memiliki peluang lebih besar untuk dipahami oleh siswa karena sudah dipelajari sejak SMP.
Akan tetapi, hasil observasi di SMK menunjukkan bahwa sebagian besar siswa masih melakukan kesalahan dalam menyelesaikan soal. Hal ini juga didukung dengan pengalaman mengajar guru di SMK dikatakan bahwa mengajarkan suatu konsep matematika adalah suatu hal yang sulit. Siswa mampu menyelesaikan soal dengan perhitungan maupun menyelesaikan soal yang hampir sama dicontohkan oleh guru, namun akan kesulitan jika soal tersebut diubah menjadi bentuk soal yang lain dan jika dibuat dalam soal cerita.

Pemecahan masalah matematika sekolah biasanya diwujudkan melalui soal cerita. Akan tetapi, menurut Tumardi (2011, hal. 54) soal cerita merupakan pokok bahasan yang sulit dikuasai oleh siswa, tidak hanya siswa di Indonesia namun juga siswa di negara-negara lain. Hal ini dapat dilihat dari kesalahan-kesalahan yang dilakukan siswa saat menyelesaikan soal cerita yang diberikan.

Belajar matematika adalah belajar mengenai proses dan teori yang memberikan ilmu tentang suatu objek. Dalam mempelajari matematika, banyak materi yang memerlukan pengetahuan prasyarat. Apabila siswa tidak memahami konsep dari suatu materi maka akan berdampak pada materi yang akan dipelajari selanjutnya. Sehingga siswa mengalami kesulitan dalam memahami materi tersebut dan akhirnya melakukan kesalahankesalahan dalam menyelesaikan soal.

Hasil belajar siswa pada pokok bahasan sebelumnya masih rendah, terutama pada pokok bahasan persamaan kuadrat nilai rata-rata hasil belajar siswa secara klasikal mengalami penurunan. Hal ini diindikasikan bahwa banyak siswa yang belum menguasai sepenuhnya konsep menyelesaikan persamaan kuadrat. Ketidakmampuan dalam menyelesaikan persamaan kuadrat 
menunjukkan adanya indikasi kesulitan dalam menyelesaikan persamaan kuadrat yang menyebabkan timbulnya kesalahankeasalahan siswa dalam menjawab soal baik soal latihan maupun soal ulangan.

Untuk mengetahui lebih jelas di mana letak kesalahan yang dialami siswa SMK dalam menyelesaikan persamaan kuadrat maka dilakukanlah analisis kesalahan dalam penyelesaiaan persamaan kuadrat dilanjutkan dengan melihat ketuntasan belajar siswa. Pemahaman diartikan dari kata understanding (Sumarmo, 1987, hal. 116). Derajat pemahaman ditentukan oleh tingkat keterkaitan suatu gagasan, prosedur atau fakta matematika dipahami secara menyeluruh jika hal-hal tersebut membentuk jaringan dengan keterkaitan yang tinggi. Dan konsep diartikan sebagai ide abstrak yang dapat digunakan untuk menggolongkan sekumpulan objek (Depdiknas, 2003, hal. 18).

Murniasih dkk (2016, hal 71) menyatakan bahwa konsep merupakan kesatuan pengertian dari sekelompok kondisi tertentu, sehingga dapat dipakai untuk menggambarkan berbagai kondisi yang sama. Pemahaman konsep peserta didik dalam matematika sangat penting karena akan memudahkan peserta didik dalam mempelajari matematika. Hal ini sesuai dengan hasil penelitian yang dilakukan oleh Siswono (2008, hal. 40) bahwa kemampuan siswa terhadap konsep matematika yang berbeda tingkatnya menimbulkan perbedaan pada kemampuan siswa dalam menyelesaikan soal matematika.

Dalam pembelajaran matematika seringkali siswa dihadapkan dengan soal-soal yang taraf kesukarannya berbeda-beda mulai dari yang sederhana sampai ke tingkat yang rumit, tergantung dari pokok bahasannya masing-masing. Untuk mengetahui sejauhmana seorang siswa menguasai materi tersebut biasanya diberikan soal-soal latihan yang harus dikerjakan oleh siswa. Namun, terkadang pada prosedurnya terdapat kesalahan-kesalahan yang dialami siswa sehingga berpengaruh terhadap hasil belajar.

Lerner (Abdurrahman, 2003, hal. 262) mengemukakan berbagai kesalahan umum yang dilakukan oleh anak dalam mengerjakan soal-soal matematika, yaitu kurangnya pengetahuan tentang symbol, kurangnya pemahaman tenatng nilai tempat, penggunaan proses yang keliru, kesalahan perhitungan, dan tulisan yang tidak dapat dibaca sehingga siswa melakukan kekeliruan karena tidak mampu lagi membaca tulisan sendiri.

Nurul (2013, hal. 1) ada beberapa klasifikasi kesalahan dalam menyelesaikan soal matematika secara umum,yaitu antara lain letak kesalahan dan jenis-jenis kesalahan yang sering dilakukan. 1) Letak Kesalahan Pada umumnya kesalahan dalam menyelesaikan soal matematika dapat dilihat dari letak kesalahan yang sering dilakukan. Letak kesalahan itu antara lain memahami soal, pengerjaan soal, penarikan kesimpulan. 2) Jenis-Jenis Kesalahan Adapun jenis-jenis kesalahan yang sering dilakukan yang pertama adalah kesalahan konsep. Kesalahan konsep memiliki indikator diantaranya adalah menentukan dan menggunakan teorema atau rumus untuk menjawab suatu masalah. Kedua kesalahan menggunakan data. Kesalahan menggunakan data memiliki indikator diantaranya adalah tidak menggunakan data yang seharusnya dipakai dengan kata lain salah dalam memasukkan data ke variabel. Ketiga yaitu interprestasi bahasa. Dalam kesalahan interpretasi bahasa ini yaitu kesalahan dalam menyatakan bahasa sehari-hari kedalam symbol-simbol matematika atau ke dalam bahasa matematikanya. Keempat adalah kesalahan teknis. Kesalahan teknis ini meliputi 
kesalahan dalam perhitungan dan kesalahan memanipulasi bentuk aljabar. Kelima yaitu kesalahan penarikan kesimpulan. Kesalahan penarikan kesimpulan meliputi melakukan penyimpulan tanpa alasan yang mendukung.

Kesalahan yang dapat dilakukan siswa saat menyelesaikan soal matematika diantara adalah sebagai berikut: 1) Kesalahan konsep, yaitu kesalahan siswa dalam menafsirkan dan, menggunakan konsep matematika. 2) Kesalahan prinsip, yaitu kesalahan siswa dalam menafsirkan dan menggunakan rumusrumus matematika. 3) Kesalahan operasi, yaitu kesalahan siswa dalam menggunakan operasi dalam matematika. 4) Kesalahan karena kecerobohan, yaitu kesalahan siswa karena salah dalam perhitungan (Wiyartimi, 2010, hal. 91).

Berdasarkan data PISA tahun 2009 dalam Ariyadi Wijaya (2012, hal. 1-2), diperoleh hasil bahwa hampir setengah siswa Indonesia (43,5\%) tidak mampu menyelesaikan soal PISA paling sederhana. Sekitar sepertiga siswa Indonesia yaitu $(33,1 \%)$ hanya bisa mengerjakan soal dari soal kontekstual diberikan secara eksplisit serta semua data yang dibutuhkan untuk mengerjakan soal diberikan secara tepat. Hanya $0,1 \%$ siswa Indonesia mampu mengembangkan dan mengerjakan pemodelan matematika yang menuntut keterampilan berpikir dan penalaran.

Soleh (1998, hal. 39) faktor-faktor yang menyebabkan ketidakberhasilan siswa dalam belajar matematika yaitu (1) siswa tidak menangkap konsep matematika dengan benar, (2) siswa tidak menangkap arti lambanglambang, (3) siswa tidak lancar menggunakan operasi dan prosedur, (4) siswa tidak memahami asal usul suatu prinsip, (5) ketidak lengkapan pengetahuan.

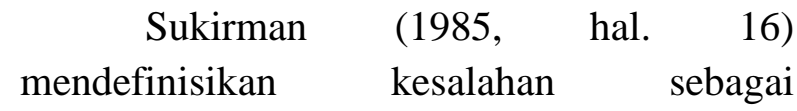
penyimpangan terhadap hal benar yang bersifat sistematis, konsisten, maupun isidental. Kesalahan bersifat sistematis dan konsisten disebabkan oleh kompetensi siswa, sedangkan kesalahan bersifat isidental tidak disebabkan oleh kompetensi siswa. Kesalahan yang banyak dilakukan oleh siswa yaitu siswa tidak menuliskan pemisalan variabel yang akan dipakai pada pembuatan model matematika yang akan mereka gunakan untuk menyelesaikan permasalahan, sehingga tidak sedikit siswa yang melakukan kesalahan ketika menyelesaikan model matematika yang telah mereka buat. Dengan demikian, untuk mengatasi kesalahan yang dilakukan siswa dalam menyelesaikan soal persamaan kuadrat perlu dilakukan analisis terhadap kesalahan yang dilakukan siswa sehingga kesalahan yang mereka lakukan dapat diminimalisir.

Dalam proses belajar mengajar akan mengahasilkan hasil belajar yang diperoleh siswa dari materi/bahan yang telah diajarkan oleh guru di kelas. Dari hasil belajar dapat diketahui sejauhmana seorang siswa dikatakan berhasil atau tuntas. Menurut Khusnul Khotimah (2016) hasil belajar adalah kemampuan yang dimiliki siswa setelah mereka menerima pengalaman belajar dalam proses pembelajaran. Prestasi belajar pada dasarnya adalah hasil yang diperoleh seseorang setelah mengikuti kegiatan belajar.Prestasi belajar biasanya dinyatakan dalam bentuk angka, simbol, huruf ataupun kalimat

Hal yang sama juga disampaikan oleh Gunarsa (2008, hal. 79) prestasi belajar adalah hasil maksimum yang dapat dicapai oleh seseorang setelah melakukan usaha belajar. Menurut Arifin (2009: 12) Prestasi belajar merupakan suatu masalah yang bersifat 
perennial dalam sejarah kehidupan manusia, karena sepanjang rentang kehidupannya manusia selalu mengejar prestasi menurut bidang dan kemampuan masing-masing. Factor-faktor penyebab kesalahan yang dilakukan siswa dalam menyelesaikan soal matematika dapat dipandang sebagai fact79orfaktor kesulitan yang dialami siswa.

\section{Metode Penelitian}

Penelitian ini dilakukan untuk memberikan gambaran letak kesalahan dalam menyelesaikan persamaan kuadrat pada siswa kelas X. Metode yang digunakan dalam penelitian ini adalah metode deskriptif dengan tujuan untuk membuat deskripsi, gambaran atau lukisan secara sistematis, factual dan akurat mengenai fakta-fakta, sifat-sifat serta hubungan antar fenomena tertentu (Suryabrata, 2003, hal. 75). Penelitian ini dilaksanakan di SMK Kesehatan. Subjek dari penelitian ini adalah siswa kelas $\mathrm{X}$ jurusan Farmasi sebanyak 65 siswa. Objek dalam penelitian yaitu kesalahan siswa dalam menyelesaikan soal matematika dan ketuntasan hasil belajar yang berkaitan dengan materi Persamaan Kuadrat.

Teknik pengumpulan data yang digunakan adalah teknik tes. Tes dalam penelitian ini digunakan untuk mengetahui letak kesalahan siswa dalam mengerjakan penyelesaian persamaaan kuadrat.

Jenis tes yang digunakan dalam penelitian ini adalah tes tertulis yang berbentuk uraian (essay) agar dapat mengetahui sejauh mana siswa mendalami suatu masalah yang diteskan dan memperkecil kerjasama antara siswa dalam mengerjakan soal (Arikunto, 2008, hal. 163). Adapun langkah-langkah penyusunan tes adalah sebagai berikut: 1) Penyusunan kisi-kisi soal tes, 2) Penulisan butir soal, 3) Validitas tes.Validitas yang digunakan dalam penelitian ini adalah validitas isi.

Tes yang diberikan terlebih dahulu dilakukan uji kevalidan dan reliabilitas. Data yang telah terkumpul dilakukan analisis dengan teknik persentase (Sudijono, 2008, hal. 58) kemudian dilakukan penilaian hasil belajar siswa.

Untuk ketuntasan belajar, jika skor minimal yang diperoleh oleh siswa sebesar $75 \%$ dari total keseluruhan maka siswa dianggap tuntas dalam menyelesaikan persamaan kuadrat.

\section{Hasil Penelitian dan Pembahasan}

Soal yang telah dibuat oleh peneliti akan diberikan ke subjek sebagai ujicoba terlebih dahulu untuk dilakukan uji validasi dan reliabilitas. Instrumen tes yang diuji cobakan untuk melihat tingkat kevalidan dan reliable soal terdiri dari dua perangkat soal yang masing-masing perangkat teridiri atas enam (6) soal. Jika soal yang telah diujikan valid maka soal tersebut dapat digunakan. Berikut hasil uji validitas dan reliable nya:

Tabel 1. Hasil Validitas dan Reliabilitas Perangkat Soal I

\begin{tabular}{lcc}
\hline \multicolumn{3}{l}{ Perangkat Soal I } \\
\hline $\begin{array}{l}\text { No } \\
\text { Soal }\end{array}$ & $\mathrm{r}_{\mathrm{xy}}$ & Ket \\
\hline $1^{*}$ & 0,765 & Valid \\
2 & 0,762 & Valid \\
3 & 0,634 & Valid \\
$4^{*}$ & 0,695 & Valid \\
5 & 0,714 & Valid \\
$6^{*}$ & 0,814 & Valid \\
\multicolumn{4}{l}{ Reliabilitas: } & 0,756 \\
\hline
\end{tabular}

Keterangan:

* : Soal yang diambil untuk penelitian 
Tabel 2. Hasil Validitas dan Reliabilitas Perangkat Soal I

\begin{tabular}{|c|c|c|}
\hline \multirow{2}{*}{\multicolumn{3}{|c|}{ Perangkat Soal II }} \\
\hline & & \\
\hline No & $r_{x y}$ & Ket \\
\hline \multicolumn{3}{|c|}{ Soal } \\
\hline 1 & 0,704 & Valid \\
\hline $2 *$ & 0,736 & Valid \\
\hline $3 *$ & 0,656 & Valid \\
\hline 4 & 0,405 & Valid \\
\hline $5^{*}$ & 0,706 & Valid \\
\hline 6 & 0,558 & Valid \\
\hline \multicolumn{3}{|c|}{ Reliabilitas: 0,623} \\
\hline
\end{tabular}

Keterangan:

* : Soal yang diambil untuk penelitian

Hasil penelitian yang dilakukan terdapat kesalahan siswa dalam menyelesaikan soal persamaan kuadarat. Kesalahan kesalahan tersebut dianalisis ke dalam dua aspek yaitu letak kesalahan siswa yang dilihat dari materi soal dan kesalahan siswa dilihat dari langkahlangkah dalam penyelesaian.

Kesalahan siswa yang dilihat dari materi soal dapat diketahui dengan melihat banyaknya kesalahan pada setiap nomor soal. Berikut hasil distribusi frekuensi kesalahan dilihat dari materi soal.

Tabel 3. Distribusi Frekuensi Kesalahan Siswa Dilihat Dari Materi Soal

\begin{tabular}{lll}
\hline Materi Soal & Frekuensi & Persentase \\
\hline $\mathbf{D}=\mathbf{0}$ & 70 & $58,33 \%$ \\
$\mathbf{D}<\mathbf{0}$ & 106 & $88,33 \%$ \\
$\mathbf{D}>\mathbf{0}$ & 94 & $78,33 \%$ \\
\hline
\end{tabular}

Keterangan:

$\mathrm{D}=$ Diskriminan

Berdasarkan tabel 3, diketahui bahwa jumlah siswa yang menjawab salah dalam menyelesaikan persamaan kuadrat lebih dominan pada soal dengan materi diskrimanan kurang dari nol $(\mathrm{D}<0)$. Kesalahan terbesar terletak pada saat menyelesaikan dan menentukan akar-akar persamaan kuadrat yang akar-akarnya berbentuk imajiner/hayal.

Tabel 4. Distribusi Frekuensi Kesalahan Siswa Pada Setiap Langkah

\begin{tabular}{lllllll}
\hline No. & \multicolumn{7}{l}{ Banyaknya kesalahan pada } \\
Soal & $\mathrm{L}_{1}$ & $\%$ & $\mathrm{~L}_{2}$ & $\%$ & $\mathrm{~L}_{3}$ & $\%$ \\
\hline 1 & 34 & 52,3 & 8 & 12,31 & 17 & 26,15 \\
2 & 4 & 6,15 & 9 & 13,85 & 20 & 30,77 \\
3 & 38 & 58,46 & 3 & 4,62 & 5 & 7,69 \\
4 & 28 & 43,08 & 11 & 16,92 & 22 & 33,85 \\
5 & 16 & 24,62 & 16 & 24,61 & 10 & 15,38 \\
6 & 45 & 69,23 & 7 & 10,76 & 12 & 18,46 \\
\hline
\end{tabular}

Keterangan:

L1 : menentukan nilai $a, b$, dan $c$

L2 : menentukan nilai diskriminan

L3 : menyelesaikan dan menentukan akarakar persamaan kuadrat menggunakan rumus $a b c$

Berdasarkan tabel 4, sebanyak 65 siswa diberikan soal persamaan kuadrat sebanyak 6 soal dengan 3 ketentuan langkah yang diharapkan. Langkah 1 menentukan nilai a, b, dan c. Dari 6 soal yang diberikan soal no 6 untuk langkah 1 (L1) sebanyak 45 siswa dari 65 siswa menjawab salah denga persetase kesalahan sebesar 69,23\%. Kemudian dilanjutkan dengan soal no 3 sebanyak 38 siswa dari 65 siswa menjawab salah. Soal yang paling sedikit menjawab salah yang dilakukan oleh siswa adalah soal no 2 yaitu sebanyk 4 siswa dari 65 siswa. Soal dibuat tidak bentuk umum sehingga siswa dituntut untuk mengubah soal menjadi bentuk umum pada persamaan kuadrat terlebih dahulu sebelum menentukan nilai $a, b$, dan $c$. Namun pada penelitian ini, didapat kebanyakkan siswa tidak lengkap dalam menyelesaikan soal yang diberikan. Hal ini yang menghambat kemampuan siswa untuk memecahkan masalah matematika termasuk tidak menangkap arti dari lambang-lambang yang ada sehingga siswa memanipulasi sendiri 
lambang-lambang yang ada dan mengakibatkan timbul kesalahan dalam menyelesaikan soal pada langkah 1 .

Pada langkah 2 (L2) yaitu dengan menentukan nilai diskriminan. Dari 65 siswa yang menjawab soal salah paling banyak yaitu soal no 5 ada sebanyak 16 siswa. Soal yang dijawab siswa paling sedikit adalah soal no 3 yaitu sebnyak 3 siswa dari 65 siswa. Dalam penelitian ditemukan bahwa kebanyakan siswa belum bisa mengaplikasikan pengetahuan yang didapat pada langkah 1 ke langkah 2 dikarenakan ketidaklancaran menggunakan operasi Dengan demikian langkah 2 dinyatakan salah, sesuai dengan kriteria pemberian skor jika langkah 2 salah maka langkah berikutnya dianggap salah.

Untuk langkah 3 (L3) yaitu menyelesaikan dan menentukan akar-akar persamaan kuadrat menggunakan rumus $a b c$. Dari 6 soal yang diberikan soal no 4 yang paling banyak menjawab salah yaitu sebanyak 22 siswa dari 65 siswa. Untuk soal yang paling sedikit dijawab salah oleh siswa adalah soal no 3 sebanyak 5 siswa dari 65 siswa. Pada langkah ini siswa dituntut untuk menyelesaikan dan menentukan akar-akar persamaan kuadrat. Dalam penelitian ditemukan bahwa kebanyakan siswa belum bisa mengaplikasikan pengetahuan yang didapat pada langkah 1 dan 2 ke langkah 3, siswa tahu rumus yang digunakan akan tetapi tidak tahu bagaimana proses dan prosedur untuk menggunakannya, sehingga terjadi kekeliruan bahkan pada saat pengoperasian aljabar dikarenakan ketidaklancaran menggunakan operasi serta prosedur terdahulu mempengaruhi pemahaman prosedur selanjutnya sehingga terjadi penggunaan proses yang keliru dan kesalahan dalam perhitungan. Dengan demikian langkah 3 dinyatakan salah, sesuai dengan kriteria pemberian skor jika langkah 1 dan 2 salah maka langkah berikutnya dianggap salah.

Tabel 5. Ketuntasan Belajar Siswa Secara Klasikal

\begin{tabular}{llll}
\hline No & Kelas & Ketuntasan & Keterangan \\
\hline 1. & XA & $39,28 \%$ & Tidak Tuntas \\
2. & XB & $68,75 \%$ & Tidak Tuntas \\
3. & XC & $21,88 \%$ & Tidak Tuntas \\
\hline
\end{tabular}

Berdasarkan hasil penelitian yang dilakukan didapat ketuntasan belajar secara klasikal pada tabel 5. Dari 3 kelas yang dijadikan subjek dalam penelitian, tidak ada yang memenuhi kriteria tuntas dengan nilai ketuntasan secara klasikal sebesar $75 \%$. Hal ini menunjukkan bahwa ketuntasan secara klasikal tidak tercapai.

Dengan melihat banyaknya persentase kesalahan yang dialami siswa, maka perlu dilakukan upaya mengatasi kesalahankesalahan ini. Hal ini sesuai dengan pendapat yang dikemukakan oleh Lerner (Abdurrahman, 2003, hal. 262) yang menyatakan bahwa berbagai kesalahan umum yang dilakukan oleh anak dalam mengerjakan soal-soal matematika, yaitu kurangnya pengetahuan tentang symbol, kurangnya pemahaman tenatng nilai tempat, penggunaan proses yang keliru, kesalahan perhitungan, dan tulisan yang tidak dapat dibaca sehingga siswa melakukan kekeliruan karena tidak mampu lagi membaca tulisan sendiri. Hal ini mengingat kemampuan menyelesaikan persamaan kuadrat sangat berperan dalam mempelajari matematika pada bagian lain dan lanjutannya. Sehingga dapat menyebabkan ketuntasan belajar pada materi persamaan kuadrat secara klasikal masih belum tercapai yaitu ketuntasan tertinggi yang diperoleh sebesar $68,75 \%$ tidak mencapai $75 \%$. 


\section{Simpulan}

Pada penelitian dapat disimpulkan bahwa letak kesalahan yang dialami siswa dalam menyelesaikan persamaan kuadrat lebih dominan pada langkah 1 yaitu menentukan nilai-nilai a, b, dan c dari persamaan kuadrat terutama pada persamaan kuadrat yang dinyatakan dalam bentuk tidak baku. Dari seluruh hasil belajar siswa menunjukkan ketuntasan belajar siswa dalam menyelesaikan persamaan kuadrat secara klasikal masih belum tercapai.

\section{Daftar Pustaka}

Abdurrahman, Mulyono. 2003. Pendidikan Bagi Anak Berkesulitan Belajar. Jakarta: Rineka Cipta.

Depdiknas. 2003. Pedoman Khusus Pengembangan Sistem Penilaian Berbasis Kompetensi SMP. Jakarta: Depdiknas.

Herman Hudojo. 2005. Pengembangan Kurikulum dan Pembelajaran Matematika. Malang: Universitas Negeri Malang Press.

Khusnul Khotimah, 2016. Pengaruh strategi pembelajaran terhadap hasil belajar di tinjjauh dari aktifitas belajar. Surakarta:

Murniasih, T., Ferdiani, R., \& Fayeldi, T.(2016). Media Smart Diagram Venn Untuk Meningkatkan Pemahaman Konsep Siswa Pada Materi Himpunan.Math Didactic: Jurnal Pendidikan Matematika, 2(2), 70-76. Retrieved from http://jurnal.stkipbjm.ac.id/index.php/m ath/article/view/30

Putri W, Mella. 2008. Analisis Kesulitan Menyelesaikan Soal Cerita Pada Pelajaran Matematika Kelas VII Semester Ganjil SMP Tri Sukses Natar
Tahun Ajaran 2008/2009. Skripsi. Lampung: Unila.

Soedjadi. 2000. Kiat Pendidikan Matematika di Indonesia (Konatatasi Keadaan Masa Kini Menuju Harapan Masa Depan). Jakarta: Ditjen Depdiknas.

Soleh, Muhammad. 1998. Pokok-pokok pengajaran Matematika Sekolah. Depdikbud: Jakarta.

Suryabrata, Sumadi. 2006. Metodologi Penelitian. Jakarta: Raja Grafindo

Sumarmo, U. 1987. Kemampuan Pemahaman dan Penalaran Matematik Siswa SMA Dikaitkan dengan Penalaran Logik Siswa dan Beberapa Unsur Proses Belajar Mengajar. Disertasi pada Pascasarjana IKIP Bandung: tidak diterbitkan.

Wijaya, Ariyadi. 2012. Pendidikan Matematika Realistik. Yogyakarta: Graha Ilmu. 